Background: Although myeloperoxidase (MPO) and adenosine-deaminase (ADA) levels are markers of activated leukocytes, both enzymes have not been currently addressed in inflammation models.

Aims: This study evaluates whether the concentrations of these enzymes are significantly correlated with the content of leukocytes in a pleurisy model. Metbods: The pleurisy was induced by carrageenan $(1 \%)$ in mice, and the parameters analyzed 4 and $48 \mathrm{~h}$ after.

Results: After the induction of inflammation $(4 \mathrm{~h})$, MPO and ADA levels peaked in parallel to neutrophils $(p<0.01)$. Regarding the second phase of pleurisy $(48 \mathrm{~h})$, the highest concentrations of ADA were detected in parallel to the highest levels of mononuclears $(p<0.01)$. At this time, MPO levels and neutrophils remained elevated, although at lower levels than those found at $4 \mathrm{~h}$. A significant positive correlation was found among neutrophils and MPO, and mononuclears and ADA $(p<0.01)$.

Conclusions: These findings support the evidence that both enzymes are markers of the inflammatory process, and provide new tools for a better understanding of the immunoregulatory pathways that occur in inflammation.

Key words: Adenosine-deaminase, Myeloperoxidase, Mouse pleurisy, Inflammation

\section{Myeloperoxidase and adenosine-deaminase levels in the pleural fluid leakage induced by carrageenan in the mouse model of pleurisy}

\author{
Tânia Silvia Fröde ${ }^{1, C A}$ and Y. S. Medeiros ${ }^{2}$
}

${ }^{1}$ Department of Clinical Analysis, Center of Health Sciences and ${ }^{2}$ Department of Pharmacology, Center of Biological Sciences, Universidade Federal de Santa Catarina, Campus Universitário - Trindade, 88040-970 Florianópolis, SC, Brazil

\footnotetext{
${ }^{\mathrm{CA}}$ Corresponding Author

Fax: +55482440936

E-mail: saleh@ccs.ufsc.br
}

\section{Introduction}

Many studies have demonstrated that the release of myeloperoxidase (MPO) or adenosine deaminase (ADA) from leukocytes at the site of injury reflects the activation of both neutrophils and lymphocytes. ${ }^{1,2}$ Myeloperoxidase is a leukocyte component able to generate potent microbicidal products and it is recognized that it facilitates cell adhesion, mainly via CD11b/CD18, a function that may be of considerable importance for leukocyte migration. ${ }^{3,4}$ In addition, ADA activity originates from the action of isoenzymes ADA-1 and ADA-2. Increased ADA activity has been found in the pleural fluid and serum of tuberculous patients as well as in the serum of patients suffering from leprosy, cutaneous leishmaniosis, brucellosis, salmonellosis and human deficiency virus infection. It has also been found in subjects with renal allograft transplants undergoing acute graft rejection. ${ }^{1,5-10}$ On the contrary, based on these findings, these two markers constitute valuable tools for use in the evaluation of the degree of inflammation. ${ }^{1,4}$

Since very little data is available regarding the changes in the two enzymes during acute and/or chronic inflammation, the aim of the present study was to examine whether the concentrations of both enzymes are significantly correlated with the differ- ential contents of leukocyte cells, namely neutrophils and lymphocytes, in a pleurisy model induced by carrageenan (1\%) in mice. A major characteristic of this model is the biphasic profile of cell migration characterized by an early $(4 \mathrm{~h})$ and late $(48 \mathrm{~h})$ cell migration of neutrophils and mononuclear cells, respectively. ${ }^{11}$ These two phases of the inflammatory response to carrageenan in the mouse pleural cavity are named 'first' (or 'early') and 'second' (or 'late') phases.

\section{Methods}

\section{Animals}

Non-fasted adult Swiss mice of both sexes (18-25 g), aged 2 months, were used throughout the experiments. The animals were kept in an environmentally controlled room, temperature $21 \pm 2^{\circ} \mathrm{C}$, under a light/ dark cycle of $12 \mathrm{~h}$, and were allowed free access to food and water. Animals were managed using the principles and guidelines for the care of laboratory animals according to Zimmermann. ${ }^{12}$

\section{Experimental design}

\section{Induction and analysis of pleurisy}

As previously reported, ${ }^{11,13}$ the mouse pleurisy was induced by a single intrapleural injection of $0.1 \mathrm{ml}$ of 
sterile saline plus carrageenan (1\%). Since the pleurisy caused by carrageenan exhibits a biphasic response ( 4 and $48 \mathrm{~h}$ ), both interval points were chosen to determine the levels of both MPO and ADA.

After killing the animals with an overdose of ether, the thorax was opened and the pleural cavity was washed with $1.0 \mathrm{ml}$ of sterile phosphate-buffered saline (PBS) containing heparin $(20 \mathrm{IU} / \mathrm{ml})$. Several samples of the pleural lavage were collected for further determination of both MPO and ADA activities as well as total and differential leukocyte contents. Total leukocyte counts were performed on an automatic counting machine (Beckman Coulter, Inc., Brea, CA, USA), whereas cytospin preparations of pleural washing were stained with May-Grunwald-Giemsa for the differential count of leukocytes, which was performed under an immersion objective.

\section{Enzymatic assays}

In-house assays of both MPO and ADA were employed according to the methods developed by Rao et al. ${ }^{14}$ and Giusti and Galanti. ${ }^{14,15}$ Using conventional reagents, each enzymatic concentration was estimated by means of colorimetric measurements (absorbances of 450 and $630 \mathrm{~nm}$, respectively) in a Hitachi spectrophotometer (U-2001, San Jose, CA, USA). One unit of MPO is defined as the activity of the enzyme that oxides $1 \mathrm{~mol}$ of $\mathrm{H}_{2} \mathrm{O}_{2} / \mathrm{min}$, whereas one unit of ADA is equivalent to the amount of enzyme required to release $1 \mathrm{mmol}$ of ammonia/min. Results were expressed as $\mathrm{mU} / \mathrm{ml}$ (MPO) and U/l (ADA).

\section{Myeloperoxidase assay}

Standard samples with different concentrations of myeloperoxidase (from human neutrophils, M6908, St. Louis, MO, USA) were prepared to obtain a standard curve in the range of $0.07-140 \mathrm{mU} / \mathrm{ml}$. Pleural aliquots $(40 \mu \mathrm{l})$ and standards were transferred to cuvettes and the reaction was initiated with the addition of $360 \mu 1$ of assay buffer $(0.167 \mathrm{mg} / \mathrm{ml}$ of $o$-dianisidine $2 \mathrm{HCl}$ and $0.0005 \% \mathrm{H}_{2} \mathrm{O}_{2}$ ). The reaction was stopped with sodium azide $1 \%$. Afterwards, the samples were centrifuged at $50 \times g$ for $5 \mathrm{~min}$, the supernatants were separated, and the rates of changes in absorbancy were determined. MPO activity was estimated by interpolation from the standard curve already described. Samples in which the levels of MPO were above the higher limit of detection $(140 \mathrm{mU} / \mathrm{ml})$ were diluted (two- to fivefold) and the concentrations were corrected for the twofold to fivefold dilution, whereas results below the lower limit of detection were expressed as $0.7 \mathrm{mU} / \mathrm{ml}$.

\section{Adenosine-deaminase assay}

Initially, standard samples (final volume of $500 \mu \mathrm{l}$ ) with different volume concentrations of $\mathrm{NaH}_{2} \mathrm{PO}_{4} \cdot \mathrm{H}_{2} \mathrm{O}$ $(35 \mathrm{mM}), \mathrm{Na}_{2} \mathrm{HPO}_{4} \cdot \mathrm{H}_{2} \mathrm{O}(15 \mathrm{mM})$ and of $\mathrm{NH}_{3} \mathrm{SO}_{4}$ (15 $\mathrm{mM}$ ) were prepared to obtain a standard curve in the range of $10-50 \mathrm{U} / \mathrm{l}$. Pleural fluid samples $(20 \mu \mathrm{l})$ were transferred to cuvettes and the reaction was initiated by the addition of adenosine phosphatebuffered solution ( $\mathrm{pH} 6.5,500 \mu \mathrm{l}$; composition, $\mathrm{NaH}_{2^{-}}$ $\mathrm{PO} 4 \cdot \mathrm{H}_{2} \mathrm{O}(35 \mathrm{mM}), \mathrm{Na}_{2} \mathrm{HPO}_{4} \cdot 12 \mathrm{H}_{2} \mathrm{O}(15 \mathrm{mM})$ and adenosine $(0.5 \mathrm{mM}))$. After incubation for $1 \mathrm{~h}$ at $37^{\circ} \mathrm{C}$, the reaction was halted with the addition of a solution $(1000 \mu \mathrm{l})$ of phenol $(1 \mathrm{mM})$ and nitroprussiate $(0.17 \mathrm{mM})$, plus alkaline buffer $(1000 \mu \mathrm{l}$ : $\mathrm{NaOCl}$, $11 \mathrm{mM}$ ). This solution (final volume of $2000 \mu \mathrm{l}$ ) was also added to the cuvettes with the different standard samples. Afterwards, the rate of change in absorbancy was determined. ADA activity was estimated by interpolation from the standard curve already described. The reagents were stable at $2-8^{\circ} \mathrm{C}$ for 1 month.

\section{Drugs}

Carrageenan (degree IV), dianisidine $2 \mathrm{HCl}$ (3, $3^{\prime}$-dimethoxybenzidine), sodium azide, human polymorphonuclear leukocyte myeloperoxidase (Sigma, St, Louis, MO, USA), $\mathrm{NaH}_{2} \mathrm{PO}_{4} \cdot \mathrm{H}_{2} \mathrm{O}, \mathrm{Na}_{2} \mathrm{HPO}_{4} \cdot 12 \mathrm{H}_{2} \mathrm{O}, \mathrm{NH}_{3} \mathrm{SO}_{4}$, nitroprussiate (Montedison, São Paulo, SP, Brazil), adenosine (Sigma, St. Louis, MO, USA), alkaline buffer (Merck, São Paulo, SP, Brazil), phenol (Biotech, São Paulo, SP, Brazil). NaCl (0.9\%), May-Grunwald-Giemsa dye from different commercial sources. PBS (Merck (pH 7.6): composition, $\mathrm{NaCl}(137 \mathrm{mmol}), \quad \mathrm{KCl}$ $(2.7 \mathrm{mmol})$ and phosphate buffer salts $(10 \mathrm{mM}))$ was previously prepared and maintained in the refrigerator. All drugs were kept in siliconized plastic tubes at $-20^{\circ} \mathrm{C}$. On the day of the experiments, the drugs were diluted to the desired concentration with sterile saline solution at room temperature.

\section{Statistical analysis}

ADA and MPO values were analyzed by use of parametric (analysis of variance and Dunnett) and nonparametric (Kruskall-Wallis and Dunn) tests. When necessary, single linear regression as well as parametric and non-parametric correlation statistical tests were also employed. $p<0.05$ was considered indicative of significance. According to the statistical methodology, values are presented as mean $\pm 95 \%$ confidence limits (CL) (parametric tests, ADA), mean \pm SEM (parametric tests, total and differential leukocytes) or median plus range (non-parametric tests, MPO).

\section{Results}

In control animals (treated only with buffered-saline solution), MPO and ADA concentrations were $3.0 \mathrm{mU} /$ $\mathrm{ml}$ (range, $2.0-3.4 \mathrm{mU} / \mathrm{ml}$ ) and $1.9 \mathrm{U} / 1$ (CL, 1.0-2.8 U/1), respectively (Fig. 1A,B). Baseline levels of neutrophil and mononuclear cells $\left(\times 10^{6}\right)$ were 0.3 \pm 0.1 and $0.8 \pm 0.1$ (Fig. 1C,D).

As shown in Fig. 1A,C, myeloperoxidase levels peaked at $4 \mathrm{~h}$ (median, $537.5 \mathrm{mU} / \mathrm{ml}$; range, 
FIG. 1. Myeloperoxidase (A), adenosine deaminase (B), neutrophil (C) and mononuclear (D) values determined for the pleural lavage in the early $(4 \mathrm{~h})$ and late $(48 \mathrm{~h})$ phases of pleurisy induced by carrageenan in mice. C, Control values obtained for sterilesaline-treated mice. Symbols indicate the median (MPO) or mean (ADA, neutrophils, mononuclears) values, and the dotted lines the respective ranges (MPO) or confidence limits (ADA). ${ }^{* *} p<0.01$.

$323.6-683.7 \mathrm{mU} / \mathrm{ml})(p<0.01)$ after pleurisy induction in parallel with neutrophils $\left(4.7 \pm 0.2 \times 10^{6}\right)$.

On the contrary, adenosine-deaminase levels peaked both at $4 \mathrm{~h}$ (mean, 5.6 U/1; CL, 5.0-6.2 U/1) $(p$ $<0.01)$ and $48 \mathrm{~h}$ (mean, 7.5 U/1; CL, 6.8-8.0 U/1) $(p<$ 0.01) after pleurisy induction (Fig. 1B). The highest concentrations of ADA were detected at $48 \mathrm{~h}$ in association with highest levels of mononuclears (6.6 $\left.\pm 0.3 \times 10^{6}\right)(p<0.01)($ Fig. 1B,D). At this time, MPO levels (median, $158.0 \mathrm{mU} / \mathrm{ml}$; range, 146.0-171.0 mU/ $\mathrm{ml})$ and neutrophils $\left(1.2 \pm 0.2 \times 10^{6}\right)$ still remained elevated, although at lower levels than those found at $4 \mathrm{~h}$ (Fig. 1A,C). It is interesting to point out that high levels of ADA were also detected $4 \mathrm{~h}$ after pleurisy induction in association with neutrophils, but not mononuclear cell migration (Fig. 1).

A significant positive correlation was detected between ADA levels and both total leukocyte $(r=$ $0.73, p<0.01)$ and mononuclear cells $(r=0.64, p<$ 0.01 ) (Fig. 2A), whereas another positive correlation 
was found between neutrophils and MPO $(r=0.47$, $P<0.01$ ) (Fig. 2B).

\section{Discussion}

Our data show that both MPO and ADA levels are increased in the pleurisy reaction induced by carrageenan in mice. Considering that this model of inflammation presents a biphasic profile, characterized by two different pools of leukocyte population, these results provide additional information on the general mechanisms of inflammation.

As a rule, MPO is involved in the killing of several microorganisms and foreign cells, including bacteria, fungi, viruses, red cells, and malignant and nonmalignant nuclear cells. ${ }^{3,4}$ This enzyme is an ironcontaining heme protein located in the azurophilic granules of neutrophil granulocytes and in the lysosomes of monocytes. ${ }^{3}$ Since MPO causes significant tissue damage, several methods besides that chosen in our study are available to determine its content, including flow cytometry and immunohistochemistry methods. Its interesting to comment, however, that the measurement of neutrophil surface marker for MPO is not a reliable indicator of cell degranulation in comparison with measurement of the enzyme activity. $^{2}$ On the contrary, detection of MPO inside the cells using immunohistochemical techniques provides only qualitative results. ${ }^{2}$ Our data is in agreement with that of others' studies, ${ }^{3,16,17}$ since it shows that in this model of inflammation both neutrophils and MPO peaked in parallel in response to the nonspecific injury caused by carrageenan in the mouse pleural cavity. Furthermore, the significant fall in MPO levels in association with a concomitant reduction in neutrophil level $48 \mathrm{~h}$ later suggests that the MPO halflife is very short. In addition, the possibility that MPO release in the early phase $(4 \mathrm{~h})$ of the inflammatory reaction may be related with the events that triggered the late mononuclear cell migration cannot be discarded. This hypothesis is based on the fact that in models of atherosclerosis MPO has been shown to indirectly induce macrophage cell activation. ${ }^{18}$ Taken together, these findings highlight the evidence that the employed MPO assay may be used as andirect marker of neutrophil activation in the site of the

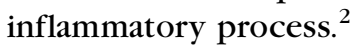

Regarding the role of ADA in inflammation, several items of data suggest that disturbances in purinergic signaling mediate the lung inflammation and damage observed in ADA-deficient mice. ${ }^{19}$ Recently, it has been demonstrated that this enzyme binds with the CD26 molecule expressed in some lymphocyte subsets. ${ }^{20}$ In addition, the possibility that this enzyme can interact with other cell-surface proteins opens up a new perspective for the research of the immunoregulatory mechanisms of the inflammatory process. In our work, significant levels of ADA were detected in both phases of the model of pleurisy studied. Although a positive correlation was found between ADA and mononuclear cell enhancement levels, increased concentrations of this enzyme $4 \mathrm{~h}$ after pleurisy induction was not clearly associated with an enhancement of mononuclear cells. These findings suggests that activation of resident cells such as pleural macrophages may be occurring at this time, since an increased enhancement of this cell is only observed $48 \mathrm{~h}$ after.

In summary, our data provide additional evidence that both MPO and ADA are involved in this particular model of pleurisy. Although it is not possible to draw definitive conclusions about these results, these findings provide new tools for a better understanding of the immunoregulatory pathway that occurs in inflammation.

ACKNOWLEDGEMENTS. The authors would like to thank Mr J.A. Amaral for providing excellent technical support during the study and the staff of the University Hospital Laboratory (Federal University of santa Catarina, Brazil) for their kind cooperation.

\section{References}

1. Blackburn MR, Datta SK, Kellems RE. Adenosine-deficient mice gen erated using a two-stage genetic engineering strategy exhibit a combined immunodeficiency. I Biol Chem 1998; 273: 5093-5100.

2. Grooteman MP, Van Tellingen A, Van Houte AJ, Bos JC, Van Limbeek M, Nube MJ. Hemodialysis-induced degranulation of polymorphonuclear cells: no correlation between membrane markers and degranulation products. Nephron 2000; 85: 267-274.

3. Klebanoff SJ. Myeloperoxidase. Proc Assoc Am Phys 1999; 11: 383-389.

4. Winterbourn CC, Vissers MC, Kettle AJ. Myeloperoxidase. Curr Opin Hematol 2000; 7: 53-58

5. Gakis G, Calia GM, Naitana AG, Pirino D, Serru G. Serum adenosine deaminase activity in HIV positive subjects. A hypothesis on the significance of ADA-2. Panminerva Med 1989; 31: 107-113.

6. Abd-Elfattah AS, Messier RH, Domkowski PW, Jones JL, Aly HM, Crescenzo DG, Wallace RB, Hopkins RA. Inhibition of adenosine deaminase and nucleoside transport. Utility in a model of homograft cardiac valve preimplantation processing. $J$ Thorac Cardiovasc Surg 1993; 105: 1095-1105.

7. Shende Rk, Bardapurke J, Patil V, Gaikwad A. Adenosine deaminase activity in leprosy. Indian J Lepr 1993; 65: 201-205.

8. Mishra OP, Gupta BL, Ali Z, Nath G, Chandra L. Adenosine deaminase activity in typhoid fever. Indian Pediatr 1994; 31: 1379-1384.

9. Erel O, Kocyigit A, Gurel MS, Bulut V, Seyrek A, Ozdemir Y. Adenosine deaminase activities in sera, lymphocytes and granulocytes in patients with cutaneous leishmaniasis. Mem Inst Oswaldo Cruz 1998; 93 491-494.

10. Knoring BE, Titarenko OT, Sakharova IA, Loginova GP, D'iakova ME Perova TI, Simbirtsev AS, Pigareva NV. Cytokine production-adenosine deaminase activity relationship in pulmonary tuberculosis. Probl Tuberk 2000; 3: 38-41.

11. Saleh TSF, Calixto JB, Medeiros YS. Anti-inflammatory effects of theophylline, cromolyn and salbutamol in a murine model of pleurisy. $\mathrm{Br} J$ Pharmacol 1996; 118: 811-819.

12. Zimmermann M. Ethical guidelines for investigations of experimental pain in conscious animals. Pain 1983; 16: 109-110.

13. Saleh TSF, Calixto JB, Medeiros YS. Effects of anti-inflammatory drugs upon nitrate and myeloperoxidase levels in the mouse pleurisy induced by carrageenan. Peptides 1999; 20: 949-956.

14. Rao TS, Currie, JL Shaffer AL, Isakson PC. Comparative evaluation of arachidonic acid (aa)- and tetradecanoylphorbol acetate (tpa)-induced dermal inflammation. Inflammation 1993; 17: 723-741.

15. Giusti G, Galanti B. Adenosine deaminase: colorimetric method. In: Bergmeyer HU, ed. Methods of Enzymatic Analysis. New York: Verlac Chemie, 1984:315-323.

16. Bainton DF. Distinct granule populations in human neutrophils and lysosomal organelles identified by immuno-electron microscopy. $J$ Immunol Methods 1999; 232: 153-168.

17. Schmekel B, Seveus L, Xu SJ, Venge P. Human neutrophil lipocalin (HNL) and myeloperoxidase (MPO). Studies of lung lavage fluid and lung tissue. Respir Med 2000; 94: 564-568. 
18. Carr AC, Myzak MC, Stocker R, McCall MR, Frei B. Myeloperoxidase binds to low-density lipoprotein: potential implications for atherosclerosis. FEBS Lett 2000; 48: 176-180.

19. Blackburn MR, Volmer JB, Thrasher JL, Zhong H, Crosby JR, Lee JJ Kellems RE. Metabolic consequences of adenosine deaminase deficiency in mice are associated with defects in alveogenesis, pulmonary inflammation, and airway obstruction. J Exp Med 2000; 192 159-170.
20. Herrera C, Casado V, Ciruela F, Schofield P, Mallol J, Lluis C, Franco R. Adenosine A (2B) receptors behave as an alternative anchoring protein for cell surface adenosine deaminase in lymphocytes and cultured cells. Mol Pharmacol 2001; 59: 127-134

\section{Received 15 May 2001;}

Accepted 5 June 2001 


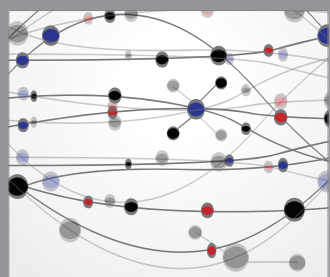

The Scientific World Journal
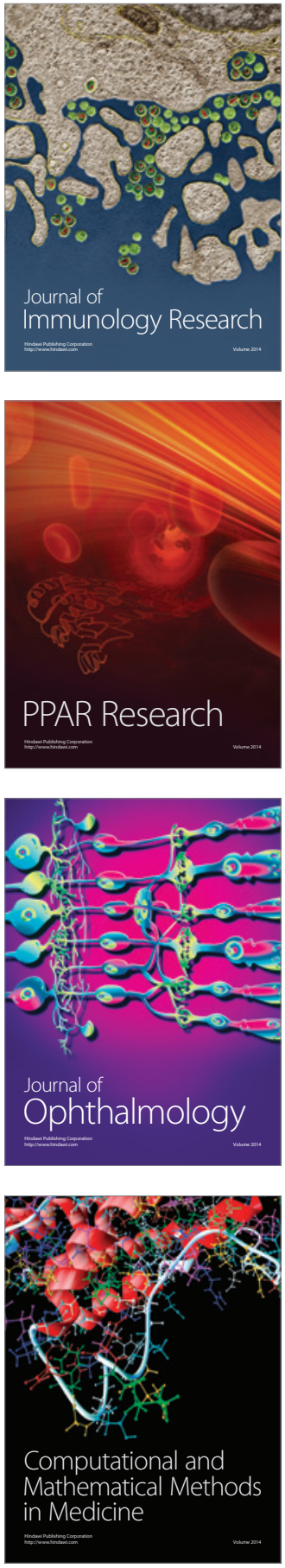

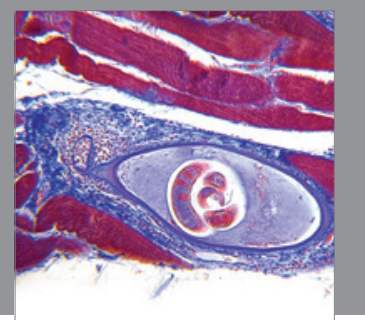

Gastroenterology

Research and Practice
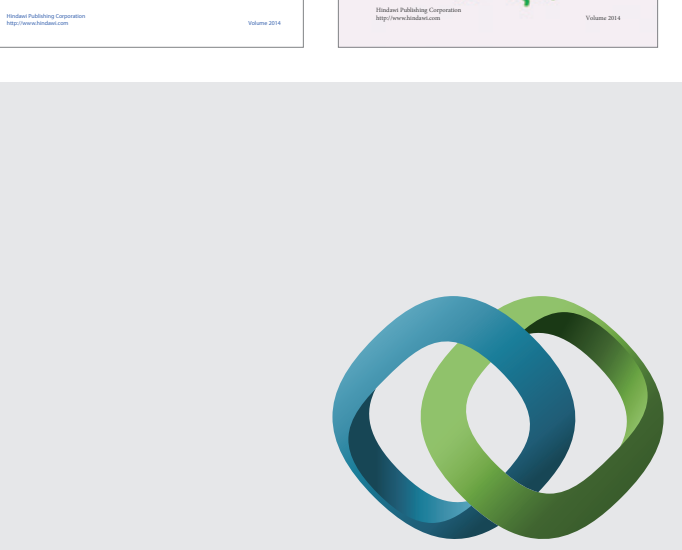

\section{Hindawi}

Submit your manuscripts at

http://www.hindawi.com
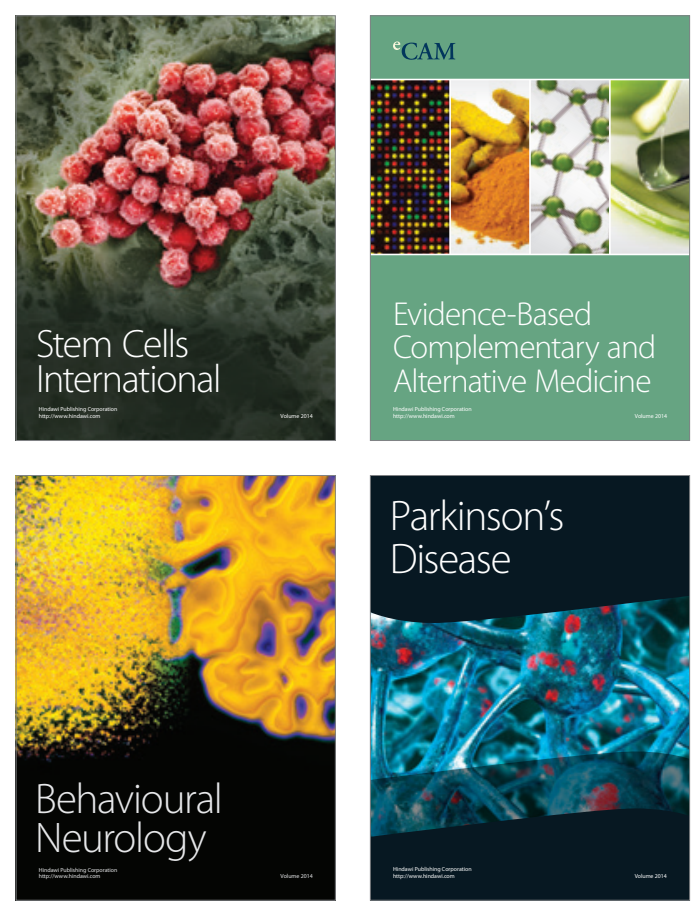

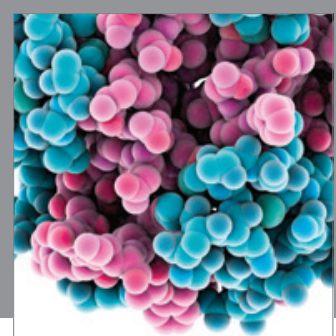

Journal of
Diabetes Research

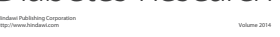

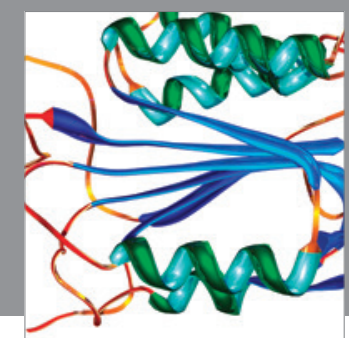

Disease Markers
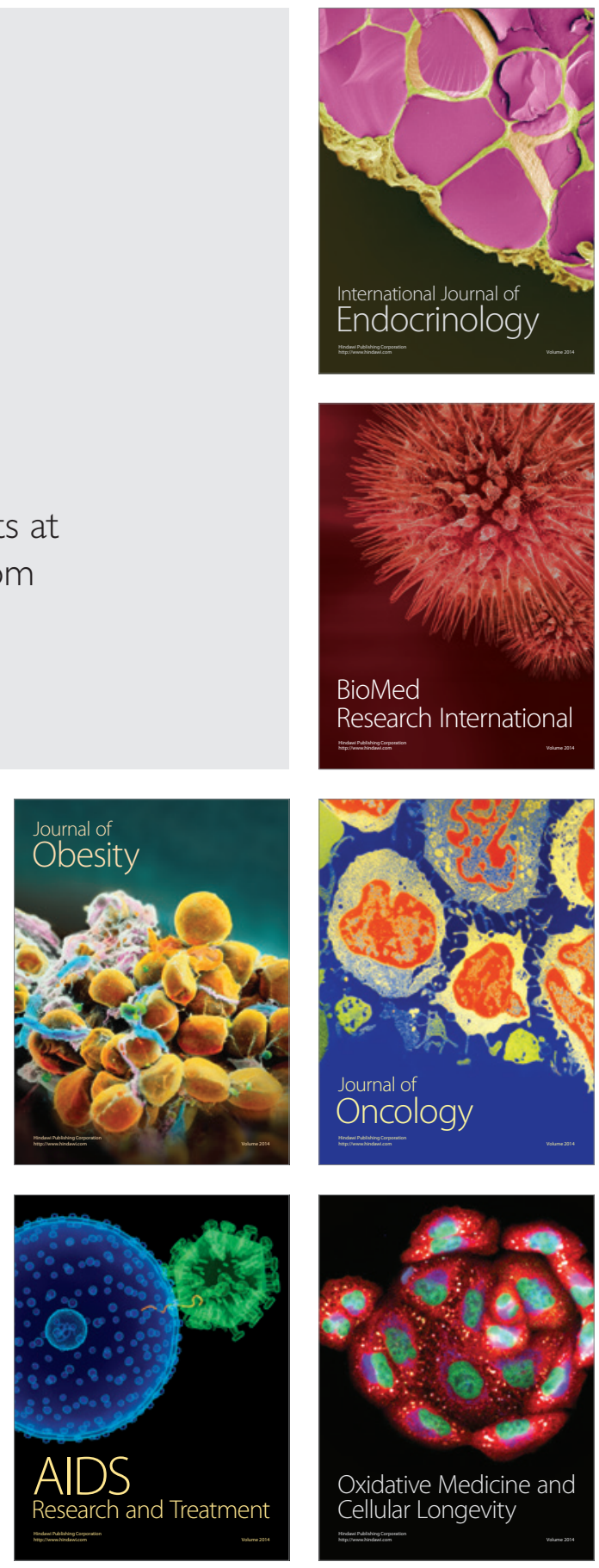